\title{
Peran Perawat Tentang Insiden yang Terjadi dalam Keselamatan Pasien
}

\author{
di Rumah Sakit
}

\author{
Sri Raudatul Jannah
}

\section{Raudatuljannahsri@gmail.com}

\section{Latar Belakang}

Patient safety merupakan prioritas, isu penting dan global dalam pelayanan kesehatan (Perry 2009). Keselamatan pasien memang menjadi isu yang terkini di kalangan masyarakat karna didasarkan atas meningkatnya kejadian yang tidak diharapkan (KTD) atau adverse event. Klasifikasi adverse event adalah kejadian nyaris cedera (KNC), kejadian tidak cedera (KTC) dan sentinel (kematian atau cedera). Contoh dari KTD seperti medication error, flebitis, dekubitus, infeksi daerah operasi, dan pasien jatuh dengan cidera (Suhartono, 2013; Suryani et al., 2011).

WHO (World Health Organitation) tahun 2004 mengumpulkan angka-angka penelitian rumah sakit di berbagai negara yaitu Amerika, Inggris, Denmark dan Australia dan ditemukan kejadian tidak diharapkan (KTD) dengan rentang 3,2\% -16,6\%. Data tersebut menjadi pemicu di berbagai negara untuk melakukan penelitian dan pengembangan sistem keselamatan pasien (Astuti, 2013).

Rumah sakit adalah salah satu institusi pelayanan kesehatan memiliki fungsi penting dalam meningkatkan derajat kesehatan masyarakat sehingga dituntut untuk selalu meningkatkan mutu pelayanan yang diberikan. Dalam layanan yang diberikan oleh tenaga medis memang tidak selalu memberikan hasil yang diharapkan oleh setiap pihak, namun hal yang bisa dilakukan adalah selalu memastikan keselamatan pasien dalam menetapkan suatau hal yang dibutuhkan oleh seorang pasien. Kualitas rumah sakit tidak hanya terlihat dari bangunan megah, dokter-dokter berpengalaman, obat-obatan yang lengkap, dan peralatan medis yang serba canggih. Rumah sakit dituntut untuk memberikan pelayanan kesehatan terbaik dan lebih terbuka pada masyarakat. Kepercayaan masyarakat terhadap mutu pelayanan kesehatan dapat ditingkatkan 
Perilaku perawat dengan kemampuan perawat sangat berperan penting dalam pelaksanaan keselamatan pasien. Perilaku yang tidak aman, lupa, kurangnya perhatian/motivasi, kecerobohan, tidak teliti dan kemampuan yang tidak memperdulikan dan menjaga keselamatan pasien berisiko untuk terjadinya kesalahan yang akan mengakibatkan cedera pada pasien. Perawat juga harus melibatkan kognitif, afektif dan tindakan yang mengutamakan keselamatan pasien dalam melakukan tindakan maupun dalam sistem pengasawan yang dilakukan perawat agar hal-hal yang tidak diinginkan terjadi pada pasien.

Keyword : Keselamatan Pasien, Perawat

\section{Metode}

Metode yang digunakan pada penelitian ini adalah metode kualitatif yaitu penelitian yang digunakan untuk meneliti pada kondisi objek alamiah, dimana peneliti merupakan instrumen kunci (Sugiyono, 2005). Serta dengan menggunakan analisa dari berbagai referensi seperti buku atau jurnal dan berfokus pada metode pembelajaran mengenai peran perawat tentang insiden yang terjadi dalam keselamatan paisen di rumah sakit. Referensi adalah sesuatu yang dipakai dalam pemerian informasi untuk memperkuat pernyataan dengan tegas, atau sering disebut juga dengan "rujukan". Sumber materi referensi ialah tempat materi itu ditemukan.

Dalam pengambilan data yang dilakukan secara menganalisa data dari beberapa jurnal dan buku yang ada serta mendapatkan referensi gabungan yang di tuangkan dalam jurnal ini. Sumber yang digunkan adalah sumber yang terbit dari mulai tahun 2012 hingga sekarang.

\section{Hasil}

Hal yang meliputi peran perawat dalam insiden yang terjadi pada keselamatan pasien di rumah sakit yang juga meliputi, kejadian tidak diharapkan (KTD), kejadian nyaris cedera (KNC), kejadian tidak cedera (KTC), kejadian potensial cedera (KPC) dan sentinel. Hal yang terjadi menimpa pasien atau kejadian lain yang menimpa keluarga dan pengunjung. Perawat juga harus memahami tindakan yang akan diambil dengan melakukan laporan Insiden Keselamatan Pasien KKP-RS merupakan suatu pelaporan anonim dan tertulis ke KKP-RS setiap KTD atau KNC yang terjadi pada pasien yang kemudian dilakukan analisis penyebab, 
rekomendasi dan solusinya, terhadap bagaimana alur pelaporan yang dimiliki oleh rumah sakit.

Dalam melakukan penanganan oleh perawat tentang insiden yang terjadi pada keselamatan di rumah sakit, juga ada beberapa faktor yang didapatkan tentang tidak adanya laporan terjadinya insiden tersebut. Hal itu adalah

- Kurang optimalnya pelaksanaan sistem pelaporan IKP

- Kurangnya pengetahuan petugas tentang kasus apa saja yang harus dilaporkan sebagai IKP

- karena petugas merasa takut akan konsekuensi negatif yang akan diterima jika melaporkan

- Kecenderungan petugas yang hanya melaporkan insiden yang mengakibatkan cedera pada pasien

Dari tanggapan beberapa perawat membuat hal tentangg pelaporan IKP yang tidak menimbulkan cedera pasien cenderung tidak dilaporkan padahal rumah sakit sudah berupaya untuk mendorong keberanian petugas untuk melapor. Tindakan yang tidak dilaporkan tersebut juga sering menjadi isu di klangan masyarakat tetang adanya kelalayan dalam menangani keselamatan pasien di rumah sakit.

Salah satu upaya untuk meminimalkan insiden atau kejadian patient safety, keperawatan sebagai pelayanan profesional yang merupakan ujung tombak pelayanan kepada pasien harus bertindak dengan didasari oleh ilmu pengetahuan termasuk pengetahuan tentang patient safety, sehingga asuhan keperawatan yang diberikan berkualitas dan bermanfaat dalam mencegah insiden kejadian tidak diharapkan atau KTD (Arumaningrum, 2014).

\section{Pembahasan}

Keselamatan telah menjadi isu global termasuk juga untuk rumah sakit. Kesalamatan pasien merupakan sebuah sistem yang membuat asuhan pasien lebih aman. Sistem tersebut terdiri dari asesmen risiko, identifikasi dan pengelolaan risiko pasien, pelaporan dan analisis insiden, kemampuan belajar dari insiden dan tindak lanjutnya, serta implementasi solusi untuk meminimalkan timbulnya risiko dan mencegah terjadinya cedera yang disebabkan oleh kesalahan akibat melakukan suatu tindakan atau tidak mengambil tindakan yang seharusnya 
diambil. Insiden keselamatan pasien merupakan setiap kejadian yang tidak disengaja dan kondisi yang mengakibatkan atau berpotensi mengakibatkan cedera yang dapat dicegah pada pasien (Kementerian Kesehatan RI, 2017).

Patient Safety adalah suatu sistem yang mencegah terjadinya Kejadian Tidak Diharapkan (KTD) akibat tindakan yang dilakukan atau bahkan tidak dilakukan oleh tenaga medis maupun non medis. Sistem tersebut meliputi: assessmen resiko, identifikasi dan pengelolaan hal yang berhubungan dengan risiko pasien, pelaporan dan analisis insiden, kemampuan belajar dari insiden dan tindak lanjutnya serta implementasi solusi untuk meminimalkan timbulnya resiko (Depkes, 2008).

Inti dari patient safety yaitu penghindaran, pencegahan dan perbaikan dari kejadian yang tidak diharapkan atau mengatasi cedera-cedera dari proses pelayanan kesehatan (Ballard, 2003). Sehingga, program utama patient safety yaitu suatu usaha untuk menurunkan angka kejadian tidak diharapkan (KTD) yang sering terjadi pada pasien selama dirawat di rumah sakit yang sangat merugikan baik pasien maupun pihak rumah sakit.

Peran perawat sebagai pemberi asuhan keperawatan dan terlibat kontak langsung dengan pasien sangat berkaitan dengan terjadinya infeksi nasokomial. Perawat bertanggung jawab menyediakan lingkungan yang aman bagi pasien terutama pencegahan infeksi. Perawat dalam menghadapi tuntutan masyarakat yang semakin tinggi terhadap mutu pelayanan keperawatan kiranya kemampauan dalam pencegahan risiko pasien jatuh perlu ditingkatkan. Komitmen bersama merupakan kunci keberhasilan dari peningkatan mutu keselamatan pasien. Adanya standar prosedur operasional yang jelas menjadi panduan bagi perawat bekerja sesuai standar minimal yang berlaku. Fasilitas rumah sakit pun perlu ditingkatkan seperti penyediaan format pengkajian resiko jatuh dan gelang identifikasi, tanda resiko jatuh.

Insiden keselamatan pasien di rumah sakit akan memberikan dampak yang merugikan bagi pihak rumah sakit, staf dan pasien pada khususnya karena sebagai penerima pelayanan. Dampak yang ditimbulkan adalah menurunnya tingkat kepercayaan masyarakat terhadap pelayanan kesehatan yang terjadi akibat rendahnya kualitas dan mutu asuhan yang diberikan. Banyak hal yang membuat masyarakat berfikiran seperti itu dikarenakan hal yang mereka dapatkan saat melakukan perawataan atau berkunjung ke rumah sakit. 
Tenaga medis memiliki peran penting dalam menciptakan pelayanan kesehatan yang bermutu. Di antaranya dalam menerapkan budaya keselamatan pasien. Saat ini keselamatan pasien belum sepenuhnya menjadi budaya dalam pelayanan kesehatan.

Budaya keselamatan pasien merupakan hal yang penting. Budaya keselamatan pasien akan menurunkan adverse event (AE) sehingga akuntabilitas rumah sakit di mata pasien dan masyarakat akan meningkat. Budaya keselamatan pasien membantu organisasi mengembangkan clinical governance, organisasi dapat lebih menyadari kesalahan yang telah terjadi, menganalisis dan mencegah bahaya atau kesalahan yang akan terjadi, mengurangi komplikasi pasien, kesalahan berulang serta sumber daya yang diperlukan untuk mengatasi keluhan dan tuntutan.

Standar keselamatan pasien tersebut terdiri dari tujuh standar yaitu :

1. Hak pasien

2. Mendidik pasien dan keluarga

3. Keselamatan pasien dan kesinambungan pelayanan

4. Penggunaan metode-metode peningkatan kinerja untuk melakukan evaluasi dan program peningkatam keselamatan pasien

5. Peran kepemimpinan dalam meningkatkan keselamatan pasien

6. Mendidik staf tentang keselamatam pasien

7. Komunikasi merupakian kunci bagi staf untuk mencapei keselamatan pasien

Keberhasilan penerapan patient safety, khususnya sarana pelayanan rumah sakit, perlu diperhatikan beberapa aspek berikut (Cahyono, 2008):

- Diperlukan kepemimpinan dan budaya yang terbuka, adil disertai komitmen dan fokus yang kuat untuk keselamatan pasien

- Rumah sakit dengan padat kerumitan, dimulai dengan adanya bauran berbagai profesi yang tersebar secara struktur yang seringkali kaku. Dalam kerumitan ini maka keselamatan pasien rawan terjadi bila "multi system teamwork" melemah.

- Diperlukan paradigma baru yang hanya dapat dilaksanakan melalui sistem pelaporan insiden keselamatan pasien yang aman.

- Dipelukan penggerak yang terlatih dalam bidang keselamatan pasien dan risiko medis.

- Pengembangan komunikasi dengan pasien dan keluarganya. 


\section{Penutup}

Dalam menerapkan keselamatan pasien merupakan suatu sistem yang mencegah terjadinya Kejadian Tidak Diharapkan (KTD) akibat tindakan yang dilakukan atau bahkan tidak dilakukan oleh tenaga medis maupun non medis. Serta memberikan pengarahan terhadap pasien apabila ingan melakukan tindakan dan membutuhkan bantuan untuk meminta perawat membantunya agar mengurangi resika dari terjadinya hal yang tidak di harapkan.

Penerapan perawat tentang insiden dalam keselamatan pasien, harus memiliki perhatian yang lebih serius dari pihak rumah sakit. Serta mulai membimbing para perawat agar dapat melaporkan kejadian atau insiden yang terjadi terhadap pasien agar dapat segera ditangani, dan tidak terjadi isu di masyarakat yang membuat hal tersebut menjadi perbincangan. Serta perawat harus memiliki dasar yang baik dalam menangani insiden yang terjadi dan pemahaman tentang tindakan dan tahapan pelaporan insiden ke pihak rumah sakit.

\section{Daftar Pustaka}

1. Gunawan,. Fajar. Y. W., \& Tatong. H. (2015). Analisis Rendahnya Laporan Insiden Keselamatan Pasien di Rumah Sakit. Jurnal Kedokteran Brawijaya, 28(2), 206-213.

2. Ismainar, H. (2015). Keselamatan Pasien Di Rumah Sakit. CV Budi Utama.

3. Isnaini. N. M., \& Muhamad. R. (2014). Pengalaman Perawat Pelaksana dalam Menerapkan Keselamatan Pasien. Jurnal Managemen Keperawatan, 2(1), 30-37.

4. Lombogia. A., Julia. R., \& Michael. K. (2016). Hubungan Perilaku Dengan Kemampuan Perawat Dalam Melaksanakan Keselamatan Pasien (Patient Safety) Di Ruang Akut Instalasi Gawat Darurat Rsup Prof. Dr. R. D. Kandou Manado. e-journal Keperawatan (e-Kp), 4(2), 1-8.

5. Mudayana. A. A. (2014). Peran Aspek Etika Tenaga Medis Dalam Penerapan Budaya Keselamatan Pasien di Rumah Sakit. Supplemen Majalah Kedokteran Andalas, 37(1), $1-6$.

6. Nivalinda. D., M. C. Inge. H., \& Agus. S. (2013). Pengaruh Motivasi Perawat dan Gaya Kepemimpinan Kepala Ruang Terhadap Penerapan Budaya Keselamatan Pasien Oleh Perawat Pelaksana Pada Rumah Sakit Pemerintah di Semarang. Jurnal Managemen Keperawatan, 1(2), 138-145. 
7. Nursery., \& Septi. M. C. (2018). Pelaksanaan Enam Sasaran Keselamatan Pasien Oleh Perawat dalam Mencegah Adverse Event di Rumah Sakit. Jurnal Keperawatan Suaka Insan, 3(2), 1-10.

8. Pambudi. Y. D. W., Ani. S., \& Dudella. D. F. Y. (2018). Faktor-Faktor Yang Mempengaruhi Perawat Dalam Penerapan 6 Skp (Sasaran Keselamatan Pasien) Pada Akreditasi JCI (Joint Commission International) di Ruang Rawat Inap Rumah Sakit Panti Waluya Malang. Nursing News, 3(1), 729-747.

9. Simamora, R. H., \& Nurmaini, C. T. S. (2019). Knowledge of Nurses about Prevention of Patient Fall Risk in Inpatient Room of Private Hospital in Medan. Indian Journal of Public Health Research \& Development, 10(10), 759-763.

10. Tristantia. A. D. (2018). Evaluasi Sistem Pelaporan Insiden Keselamatan Pasien di Rumah Sakit. Jurnal Administrasi Kesehatan Indonesia, 6(2), 83-94.

11. Triwibowo. C., Sulhah. Y., \& Nur. A. H. (2016). Handover Sebagai Upaya Peningkatan Keselamatan Pasien (Patient Safety) di Rumah Sakit. Jurnal Keperawatan Soedirman (The Soedirman Journal of Nursing), 11(2), 76-80. 